\title{
Influence of Sandstone Layered Structure and Characteristics in Coal Overburden on Mining Subsidence
}

\author{
Yan-jie SUN* \\ College of Geology \& Environment \\ Xi' an University of Science and Technology \\ Xi' an, China \\ 747720426@qq.com \\ Shi-jie SONG \\ College of Geology \& Environment \\ Xi' an University of Science and Technology \\ $\mathrm{Xi}$ an, China \\ 470634101@qq.com
}

\author{
Xiao-guang ZHAO \\ College of Geology \& Environment \\ Xi' an University of Science and Technology \\ Xi' an, China \\ 898678322@qq.com \\ Wen-jie NIE \\ College of Geology \& Environment \\ Xi' an University of Science and Technology \\ Xi' an, China \\ 76977485@qq.com
}

\begin{abstract}
Taking the coal-bearing strata with fine sandstonesiltstone interbedded structure as the example, 12 different types of stratified structure models were constructed with the quantity of rock strata, rock-soil ratio and mining depth as the variables. Based on the theory of key stratum, the stability of overburden structure with different variables was analyzed by geological method, mechanics method and regression analysis method. The influence of these three factors on mining subsidence was revealed.
\end{abstract} depth

Keywords-mining subsidence; strata; rock-soil ratio; mining

\section{INTRODUCTION}

China's current energy consumption structure the amount of coal resources accounted for about $95 \%$ of the total domestic fossil energy and China is currently the world's largest coal producer and consumer. The coal resources are widely distributed and the conditions of coal seams are diverse and the geological conditions are extremely complex[1]. For China's economic development coal plays a vital role. However mining subsidence caused by coal mining is the most common and long-term but also the most serious geological and environmental problems[2]. Song Zhenqi[3] put forward the "transfer rock beam hypothesis"; Deng Kazhong[4]proposed in the rock mining subsidence structural effects. Among them the "critical layer theory" put forward by Qian Minggao[5] academician has been widely applied in China's rock pressure theory and engineering practice.

In this paper, three factors influencing the stability of overlying bedrock in goaf are analyzed by means of geology, mechanics and mathematics based on "key layer theory".

\section{ANALYSIS OF INFLUENCE LAWS BASED ON GEOLOGY MECHANICS AND MATHEMATICAL MODELS}

\section{A. Analysis of Influence Law Based on Geology}

Therefore this paper first calculates the basic quality index (BQ) of the rock mass and then analyzes the influence of the rock mass on the stress and the water. The rock mass basic quality indexes classification method is used to evaluate the stability of the coal strata overburden. And structural factors to be considered in order to amend the BQ and finally based on " rock mass grading " and " engineering rock classification standards " for classification of coal-rock strata to find the seam overlying bedrock layer rock-soil ratio And the thickness of the three factors of the impact on mining subsidence .

\section{B. Analysis of Influence Law Based on Mechanics}

In the process of coal mining the stress and deformation of the upper strata of the coal-bearing strata can be regarded as two-end consolidation beam structure under elastic or near elastic conditions.

\section{The Influence Law Based on Mathematical Method}

In order to find out the effect of rock stratum rock-soil ratio and mining depth on coal mining subsidence three factors are set as the independent variables of mining subsidence. And the relationship between the maximum tensile stress and the maximum deflection of the overlying strata was fitted by EXCLE multiple regression analysis.

\section{STUDY ON THE INFLUENCE LAW OF THE INTER-LAYER STRUCTURE OF FINE POWDER}

\section{A. Influence of Rock Formation Number on Goaf}

The overlying strata of the coal seam are five sand layers with different layers of fine powder interbedded structure. 
The thickness of overlying rock and soil is $250 \mathrm{~m}$, the ratio of rock and soil is $3: 1$, and the corresponding quantity of rock strata is $10,12,20,30$, and 40 layers. Five models of A1, A2, A3, A4 and A5 were set up according to different strata. The model parameters are shown in Table 1 .

TABLE I. TYPES AND GEOMETRICAL PARAMETERS OF LAYERED LAYERS

\begin{tabular}{|c|c|c|c|c|c|}
\hline \multirow{2}{*}{$\begin{array}{c}\text { Ratio of rock } \\
\text { to soil }\end{array}$} & \multirow{2}{*}{ Model } & \multirow{2}{*}{$\begin{array}{l}\text { Loess (layers } \\
\text { / thickness) }\end{array}$} & \multirow{2}{*}{$\begin{array}{l}\text { Red soil (layer } \\
\text { / thickness) }\end{array}$} & \multicolumn{2}{|c|}{$\begin{array}{l}\text { Fine sandstone interbeds (layers } \\
\text { / thickness) }\end{array}$} \\
\hline & & & & $\begin{array}{c}\text { Fine } \\
\text { sandstone }\end{array}$ & Siltstone \\
\hline \multirow{5}{*}{ 3:1 } & A1 & $1 / 25 \mathrm{~m}$ & $1 / 37.5 \mathrm{~m}$ & $5 / 18.75 \mathrm{~m}$ & $5 / 18.75 \mathrm{~m}$ \\
\hline & $\mathrm{A} 2$ & $1 / 25 \mathrm{~m}$ & $1 / 37.5 \mathrm{~m}$ & $6 / 15.625 \mathrm{~m}$ & $6 / 15.625 \mathrm{~m}$ \\
\hline & $\mathrm{A} 3$ & $1 / 25 \mathrm{~m}$ & $1 / 37.5 \mathrm{~m}$ & $10 / 9.375 \mathrm{~m}$ & $10 / 9.375 \mathrm{~m}$ \\
\hline & A4 & $1 / 25 \mathrm{~m}$ & $1 / 37.5 \mathrm{~m}$ & $15 / 6.25 \mathrm{~m}$ & $15 / 6.25 \mathrm{~m}$ \\
\hline & A5 & $1 / 25 \mathrm{~m}$ & $1 / 37.5 \mathrm{~m}$ & $20 / 4.6875 \mathrm{~m}$ & $20 / 4.6875 \mathrm{~m}$ \\
\hline
\end{tabular}

\section{1) Rock mass basic quality index}

The modified BQ is evaluated according to the "rock mass grading" (GB50086-2001). The calculation results are shown in Table 2.

TABLE II. 5 TYPES OF ROCK MASS BASIC QUALITY EVALUATION

\begin{tabular}{|c|c|c|c|c|c|c|c|c|}
\hline \multirow{2}{*}{$\begin{array}{l}\text { Model } \\
\text { code }\end{array}$} & \multirow{2}{*}{$R_{C}(\mathrm{MPa})$} & \multirow{2}{*}{$\boldsymbol{K}_{v}$} & \multicolumn{3}{|c|}{ Correction factor } & \multicolumn{2}{|c|}{$\begin{array}{c}\text { Rock mass basic } \\
\text { quality index }\end{array}$} & \multirow{3}{*}{$\begin{array}{c}\text { Rock } \\
\text { mass } \\
\text { grading }\end{array}$} \\
\hline & & & $K_{t}$ & $K_{2}$ & $K_{3}$ & $B Q$ & {$[B Q]$} & \\
\hline A1 & 60 & $0.75 \sim 0.55$ & 0 & 0.2 & 0.5 & $4588 \sim 408$ & $388 \sim 338$ & \\
\hline A2 & 60 & $0.55 \sim 0.35$ & 0 & 0.2 & 0.5 & $408 \sim 358$ & $338 \sim 288$ & IV \\
\hline A3 & 60 & $0.55 \sim 0.35$ & 0 & 0.2 & 0.5 & $408 \sim 358$ & $338 \sim 288$ & IV \\
\hline A4 & 60 & $0.35 \sim 0.15$ & 0 & 0.2 & 0.5 & $358 \sim 308$ & $288 \sim 238$ & $\mathrm{IV} \sim \mathrm{V}$ \\
\hline A5 & 60 & $<0.15$ & 0 & 0.2 & 0.5 & $<308$ & $<238$ & $\mathrm{~V}$ \\
\hline
\end{tabular}

Where $R_{C}$ is the uniaxial compressive strength of the rock and $K_{V}$ is the rock mass integrity factor.

Since the influence of bedrock on mining subsidence is mainly considered in this paper, the influence of groundwater on mining subsidence will not be considered first, and the value of $K_{1}$ is 0 .Assuming that the plane is parallel to the strike-axis of the gob, the value of $K_{2}$ is 0.2. Since only the gravity field in the model, since the depth of the coal seam within the $500 \mathrm{~m}$, calculated by the five models of stress are within the high stress range, so the value of $K_{3}$ is 0.5 .

It can be seen from Table 2 that the rock mass quality of the model A1 is III IV, and the lithology of the rock mass is relatively hard rock or soft and hard rock interbed, the rock mass is relatively complete and the stability is strong. The rock mass is more complete and relatively fragile, and the stability is stronger. The rock mass of model A4 is IV to V, and the lithology of the rock mass is soft rock or hard rock interbed. The rock mass is more broken and broken, and the stability is weak. The rock mass of model A5 is $\mathrm{V}$, the lithology of rock mass is mainly soft rock, and some soft rock and rock are broken.

\section{2) Research on mining subsidence by mechanics}

The maximum tensile stress and deflection of the above model is obtained by calculating and analyzing the five models A1, A2, A3, A4 and A5 according to the mechanics equation(In order to facilitate the mapping, it will not be shown in the span on the map, all of this type of graphs do not does that).
TABLE III. THE MAXIMUM TENSILE STRESS AND DEFLECTION RESULTS OF THE 5 MODELS

\begin{tabular}{|c|c|c|c|c|c|c|}
\hline \multirow[b]{2}{*}{$\begin{array}{l}\text { Model } \\
\text { code }\end{array}$} & \multicolumn{3}{|c|}{$\begin{array}{l}\text { Model load(kN/m) } \\
\end{array}$} & \multirow[b]{2}{*}{$E(\mathbf{k P a})$} & \multirow[b]{2}{*}{$\begin{array}{c}\text { Max tensile } \\
\left.\text { stress(kN/ } \mathbf{m}^{2}\right)\end{array}$} & \multirow{2}{*}{$\begin{array}{c}\text { Maximum } \\
\text { deflection(10 } \\
{ }_{10} \mathrm{l}_{\mathrm{m}}\end{array}$} \\
\hline & $Q_{\text {loess }}$ & $Q_{\text {Red }}$ & $Q_{\text {Fine }}$ & & & \\
\hline A1 & 430 & 697.5 & 4556.25 & $7.24 \mathrm{E}+6$ & $0.20 * \mathrm{I}^{2}$ & $0.93 * 1^{4}$ \\
\hline A2 & 430 & 697.5 & 4556.25 & $7.24 \mathrm{E}+6$ & $0.24 * \mathrm{I}^{2}$ & $1.34 * 1^{4}$ \\
\hline A3 & 430 & 697.5 & 4556.25 & $7.24 \mathrm{E}+6$ & $0.40 * \mathrm{I}^{2}$ & $3.72 * 1^{4}$ \\
\hline A4 & 430 & 697.5 & 4556.25 & $7.24 \mathrm{E}+6$ & $0.61 * 1^{2}$ & $8.377^{4}{ }^{4}$ \\
\hline A5 & 430 & 697.5 & 4556.25 & $7.24 \mathrm{E}+6$ & $0.81 * 1^{2}$ & $14.9 * 1^{4}$ \\
\hline
\end{tabular}

Where $E$ is weighted elastic modulus .

The relationship between the number of strata and the maximum tensile stress of the five models is shown below .

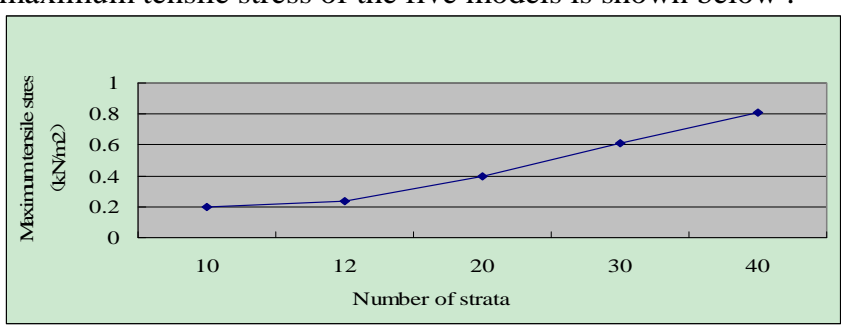

Figure 1. Relationship between layers number and maximum tensile $\left(\mathrm{kN} / \mathrm{m}^{2}\right)$

It can be seen from Fig.3 that the trend of maximum tensile stress of coal-bearing strata is increasing, which is divided into two parts:slow change and rapid change . According to mechanical equation, It can be seen that the magnitude of tensile stress is inversely proportional to the thickness of the rock. The thinner the strata are, the greater the tensile stress is, and the increasing of the strata depth will result in the thickness of the strata . Therefore, it can be seen that the maximum tensile stress of the whole rock mass will increase as the quantity of rock strata of rock strata increases, so the influence of the whole rock mass will increase gradually .

The relationship between the number of layers and maximum deflection of the five models is shown below

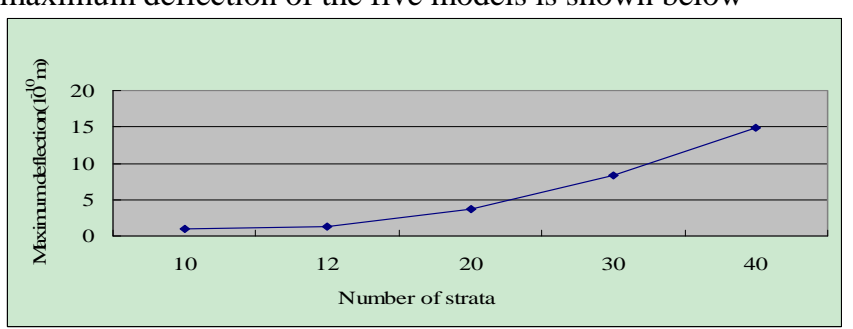

Figure 2. Number of layers and the maximum deflection (10-10m) diagram

It can be seen from Figure 2 that the relationship between the moment of inertia and the maximum deflection is inversely proportional. According to mechanical equation, the greater the thickness of the rock is, the smaller the deflection is. The smaller the thickness, the greater will be the deflection of the overburden. .The overlying bedrock will be affected gradually, which is not conducive to the stability of overlying bedrock. The maximum tensile stress and the maximum deflection of the overburden rock are increasing with the increase of the quantity of rock strata, and the stability of the overburden is also increasing. This conclusion is in accordance with the geologic calculation .And this 
conclusion and Song Shijie[6] in the coal-bearing strata found in the sandstone layer of mining subsidence consistent with the law.

\section{B. Influence of Rock - Soil Ratio on}

The coal bed is composed of four layers of rock and soil, and the depth of the coal seam is $250 \mathrm{~m}$, the number of layers is 40 , and the ratio of rock and soil is 3:1, 4:1, 7:1 and 9:1.As shown in Table 4, the corresponding models for different rock-soil ratio were A5, B5, C5, D5.

TABLE IV. TYPES AND GEOMETRICAL PARAMETERS OF LAYERED STRUCTURES OF DIFFERENT ROCK - SOIL

\begin{tabular}{|c|c|c|c|c|c|}
\hline \multirow{2}{*}{$\begin{array}{l}\text { Ratio of rock } \\
\text { to soil }\end{array}$} & \multirow{2}{*}{ Types } & \multirow{2}{*}{$\begin{array}{l}\text { Loess (layers } \\
\text { / thickness) }\end{array}$} & \multirow{2}{*}{$\begin{array}{c}\text { Red soil } \\
\text { (layer / } \\
\text { thickness) }\end{array}$} & \multicolumn{2}{|c|}{$\begin{array}{c}\text { Fine sandstone interbeds (layers } \\
\text { / thickness)) }\end{array}$} \\
\hline & & & & $\begin{array}{c}\text { Fine } \\
\text { sandstone }\end{array}$ & Siltstone \\
\hline $3: 1$ & A5 & $1 / 25 \mathrm{n}$ & $1 / 37.5 \mathrm{~m}$ & $20 / 4.6875 \mathrm{~m}$ & $20 / 4.6875 \mathrm{~m}$ \\
\hline $4: 1$ & B5 & $1 / 2$ & $1 / 30$ & $20 / 5 \mathrm{~m}$ & $20 / 5 \mathrm{~m}$ \\
\hline $7: 1$ & $\mathrm{C} 5$ & $1 / 12.5 \mathrm{~m}$ & $1 / 18.75 \mathrm{~m}$ & $20 / 5.46875 \mathrm{~m}$ & $20 / 5.46875 \mathrm{~m}$ \\
\hline $9: 1$ & D5 & $1 / 10 \mathrm{~m}$ & $1 / 15 \mathrm{~m}$ & $20 / 5.625 \mathrm{~m}$ & $20 / 5.625 \mathrm{~m}$ \\
\hline
\end{tabular}

\section{1) Rock mass basic quality index}

The corrected rock masses are calculated and corrected for the four models. The results are shown in Table 5 .

TABLE V. BASIC QUALITY EVALUATION FOR 4 MODEL ROCK MASSES

\begin{tabular}{|c|c|c|c|c|c|c|c|c|}
\hline \multirow{2}{*}{$\begin{array}{c}\text { Model } \\
\text { code }\end{array}$} & \multirow{2}{*}{$\boldsymbol{R}_{\boldsymbol{C}}$ (MPa) } & \multirow{2}{*}{$\boldsymbol{K}_{\boldsymbol{V}}$} & \multicolumn{3}{|c|}{ Correction factor } & \multicolumn{2}{c|}{$\begin{array}{c}\text { Rock mass basic } \\
\text { quality index }\end{array}$} & $\begin{array}{c}\text { Rock } \\
\text { mass } \\
\text { grading }\end{array}$ \\
\cline { 4 - 8 } & & & $K_{\boldsymbol{I}}$ & $K_{2}$ & $K_{3}$ & $B Q$ & {$[B Q]$} & \\
\hline A5 & 60 & $<0.15$ & 0 & 0.2 & 0.5 & $<307.5$ & $<237.5$ & $\mathrm{~V}$ \\
\hline B5 & 60 & $<0.15$ & 0 & 0.2 & 0.5 & $<307.5$ & $<237.5$ & $\mathrm{~V}$ \\
\hline C5 & 60 & $<0.15$ & 0 & 0.2 & 0.5 & $<307.5$ & $<23.5$ & $\mathrm{~V}$ \\
\hline D5 & 60 & $<0.15$ & 0 & 0.2 & 0.5 & $<307.5$ & $<237.5$ & $\mathrm{~V}$ \\
\hline
\end{tabular}

From Table 5, it can be seen that the grade of rock mass of model A5, B5, C5 and D5 is V, the lithology of rock mass is mainly soft rock, and some soft rock and rock are broken.

Because the basic quality index of rock mass is related to the integrity coefficient of rock mass, and the rock stratum number is the same in the above model, the rock mass integrity coefficient value is the same, and the rock mass basic quality index will not change. It can be seen that the change of rock-soil ratio has little effect on rock mass quality and stability of rock mass under the condition that thickness, structure and stratum number are invariable, Antiinterference ability has not changed.

2) Mechanics method to influence goaf

The maximum tensile stress and deflection of the four models is calculated and analyzed for the four models of A5, B5, C5 and D5 according to the mechanical equation. The results are shown in Table 6.

TABLE VI. THE MAXIMUM TENSILE STRESS AND DEFLECTION RESULTS OF THE FOUR MODELS

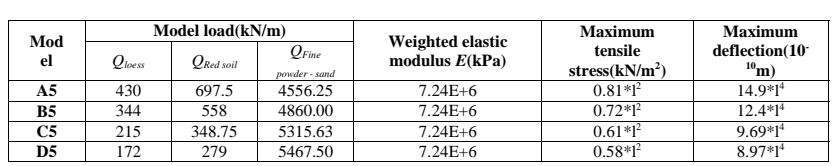

The relationship between the number of strata and maximum tensile stress is shown in the following figure.

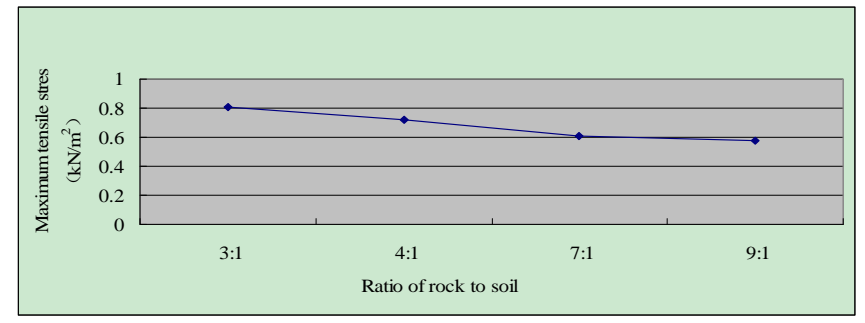

Figure 3. Rock-soil ratio and maximum tensile stress $\left(\mathrm{kN} / \mathrm{m}^{2}\right)$

It can be seen from Fig. 5 that the trend of maximum tensile stress of coal-bearing strata is divided into three stages: slow to descent-rapid to decline-slow descent. It can be found that the magnitude of tensile stress is inversely proportional to the thickness of the rock. The thinner the strata are, the greater the tensile stress is. The increase in the ratio of rock to soil will inevitably result in the increase in the thickness increase. According to the mechanical equation , It can be found that the maximum tensile stress of the entire rock mass increases with the increase of the ratio of rock to soil under the condition of the buried depth , the quantity of rock strata and the rock mass structure. The impact on the rock will be gradually increased.

The relationship between the rock-soil ratio and the maximum deflection of the four models is shown below.

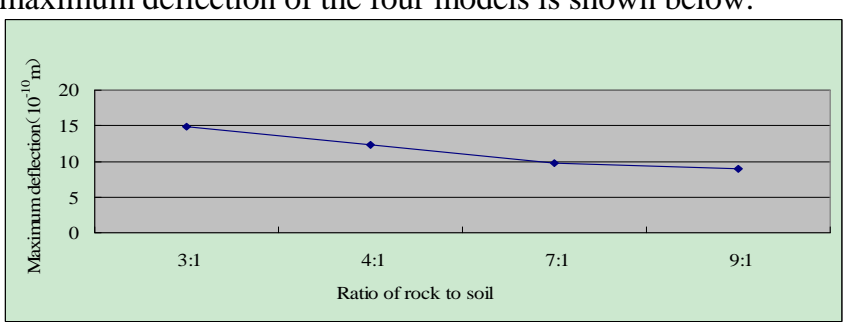

Figure 4. The relationship between soil - rock ratio and maximum deflection $\left(10^{-10} \mathrm{~m}\right)$

In general, the magnitude of the moment of inertia is directly proportional to the thickness of the rock, so the moment of inertia is inversely proportional to the maximum deflection. According to mechanical equation, the greater the layer thickness, the smaller the deflection of the overburden, because the depth and thickness Rock layer number unchanged, the greater the ratio of rock and soil to prove that the thicker rock, and therefore the smaller the deflection of overburden. With the increase in the ratio of rock to soil , the maximum deflection of the four rock mass decreases in the increase in the buried depth and the number of sand layers , so the influence of the whole rock mass will be reduced .

The maximum tensile stress and the maximum deflection of the overlying strata of coal-bearing strata decrease to the increase in the geotechnical-soil ratio, and the stability of the overlying strata is also reduced. This is due to the fact that under the same burial depth, (Sandstone) the greater the thickness of the topsoil layers thickness will be smaller . It is well known that the elastic modulus of the soil layer is smaller than that of the rock mass. Under the same external force, the soil will have a larger compression and extrusion. 
If the surface soil layer is increased, the surface subsidence will become larger.

The maximum tensile stress and the maximum deflection of the overlying strata of the coal-bearing strata of the coalbearing strata of the coal-mined-out area are smaller and the stability of the overlying strata is also reduced, which confirms that Hu Haifeng [7], the thickness of the surface layer determines the influence range and the damage extent of the surface. With the increase in the thickness of the surface soil, the influence range of the ground surfaces increases and the curvature of the surface level deformation also increased.

\section{Influence of Coal Seam Burial Depth on Mining Subsidence}

The thickness of the coal seam is three layers with different thicknesses, the layers are 20 layers, the ratio of rock and soil is 3: 1 , the burial depth of coal seam is $250 \mathrm{~m}$, 300m and 350m respectively A31, A32 and A33.

The geometrical parameters corresponding to the three different depths of bedrock are shown in the following table.

TABLE VII. TyPES AND GEOMETRICAL PARAMETERS OF LAYERED LAYERS

\begin{tabular}{|c|c|c|c|c|c|c|}
\hline \multirow{2}{*}{ 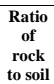 } & \multirow{2}{*}{ Model } & \multirow{2}{*}{$\begin{array}{c}\text { Buried } \\
\text { depth }\end{array}$} & \multirow{2}{*}{$\begin{array}{c}\text { Loess } \\
\text { (layers / } \\
\text { thickness) }\end{array}$} & \multirow{2}{*}{$\begin{array}{c}\text { Red soil } \\
\text { (layer / } \\
\text { thickness) }\end{array}$} & \multicolumn{2}{|c|}{$\begin{array}{l}\text { Fine sandstone interbeds (layers } \\
\text { / thickness) }\end{array}$} \\
\hline & & & & & $\begin{array}{c}\text { Fine } \\
\text { sandstone }\end{array}$ & Siltstone \\
\hline $3: 1$ & A31 & $250 \mathrm{~m}$ & $1 / 25 \mathrm{~m}$ & $1 / 37.5 \mathrm{~m}$ & $10 / 9.375 \mathrm{~m}$ & $10 / 9.375 \mathrm{~m}$ \\
\hline $3: 1$ & A32 & 300 & $1 / 30 \mathrm{~m}$ & $1 / 45 \mathrm{~m}$ & $10 / 11.25 \mathrm{~m}$ & $10 / 11.25 \mathrm{~m}$ \\
\hline $3: 1$ & A33 & $350 \mathrm{~m}$ & $1 / 35 \mathrm{~m}$ & $1 / 52.5 \mathrm{~m}$ & $10 / 13.125 \mathrm{~m}$ & $10 / 13.125 \mathrm{~m}$ \\
\hline
\end{tabular}

Rock mass basic quality index

The basic quality of the three models is calculated and corrected, and the results are shown in Table 8.

TABLE VIII. 3 KINDS OF ROCK MASS BASIC QUALITY EVALUATION

\begin{tabular}{|c|c|c|c|c|c|c|c|c|}
\hline \multirow{2}{*}{$\begin{array}{c}\text { Model } \\
\text { code }\end{array}$} & \multirow{2}{*}{$\boldsymbol{R}_{\boldsymbol{C}}$ (MPa) } & \multirow{2}{*}{$\boldsymbol{K}_{\boldsymbol{V}}$} & \multicolumn{3}{|c|}{ Correction factor } & \multicolumn{2}{c|}{$\begin{array}{c}\text { Rock mass basic } \\
\text { quality index }\end{array}$} & $\begin{array}{c}\text { Rock } \\
\text { mass } \\
\text { grading }\end{array}$ \\
\cline { 4 - 9 } & & & $K_{1}$ & $K_{2}$ & $K_{3}$ & $B Q$ & {$[B Q]$} & BQ \\
\hline A31 & 60 & $0.55 \sim 0.35$ & 0 & 0.2 & 0.5 & $408 \sim 358$ & $338 \sim 288$ & IV \\
\hline A32 & 60 & $0.55 \sim 0.35$ & 0 & 0.2 & 0.5 & 4083538 & $338 \sim 28$ & IV \\
\hline A33 & 60 & $0.55 \sim 0.35$ & 0 & 0.2 & 0.5 & $408 \sim 358$ & $338 \sim 288$ & IV \\
\hline
\end{tabular}

It can be seen from Table 8 that the rock mass quality of the model A31, A32, A33 is IV, and the lithology of the rock mass is stronger than that of the hard rock or the soft and hard rock, the rock is more complete and more fragile and stable.

The three models A31, A32 and A33 are used to calculate and analyze the structural mechanics according to mechanical equation. The maximum tensile stress and deflection of the four models are obtained.

TABLE IX. THE MAXIMUM TENSILE STRESS AND DEFLECTION RESULTS OF 3 MODELS

\begin{tabular}{|c|c|c|c|c|c|c|}
\hline \multirow{2}{*}{$\begin{array}{c}\text { Model } \\
\text { code }\end{array}$} & \multicolumn{3}{|c|}{ Model load(kN/m) } & \multirow{2}{*}{$\begin{array}{l}\text { Weighted elastic } \\
\text { modulus } E(\mathrm{kPa})\end{array}$} & \multirow{2}{*}{$\begin{array}{l}\text { Maximum tensile } \\
\text { stress }\left(\mathbf{k N} / \mathbf{m}^{2}\right)\end{array}$} & \multirow{2}{*}{$\begin{array}{c}\text { Maximum } \\
\text { deflection(10 } \\
\left.{ }^{10} \mathrm{~m}\right)\end{array}$} \\
\hline & $Q_{\text {loess }}$ & $Q_{\text {Red }}$ & $Q_{\text {Fine powder }}$ & & & \\
\hline A31 & 430 & 697.5 & 4556.25 & $7.24 \mathrm{E}+6$ & $0.40 * 1^{2}$ & $3.72 * 1^{4}$ \\
\hline $\mathrm{A} 32$ & 516 & 837 & 5466.50 & $724 \mathrm{E}+6$ & 0 & $258 * 4^{4}$ \\
\hline A33 & 602 & 976.5 & 6378.75 & $7.24 \mathrm{E}+6$ & $0.29 * l^{2}$ & $1.90^{*} 1^{4}$ \\
\hline
\end{tabular}

The relationship between the number of strata and maximum tensile stress is shown in the following figure.

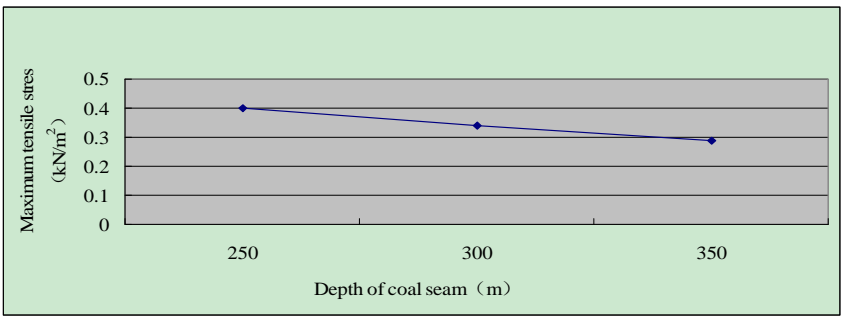

Figure 5. Buried depth and the maximum tensile stress $\left(\mathrm{kN} / \mathrm{m}^{2}\right)$ diagram

The tensile stress is inversely proportional to the thickness of rock strata. The thinner the strata are, the higher the tensile stress is, the greater the thickness of rock strata will be increasing. According to the mechanical equation, It can be found that the maximum tensile stress of the whole rock mass decreases from the increase in the buried depth and the ratio of rock-soil ratio, sand layer and rock structure is unchanged. The body will be affected by the gradual reduction. The relationship between the rock-soil ratio and the maximum deflection of the three models is shown below.

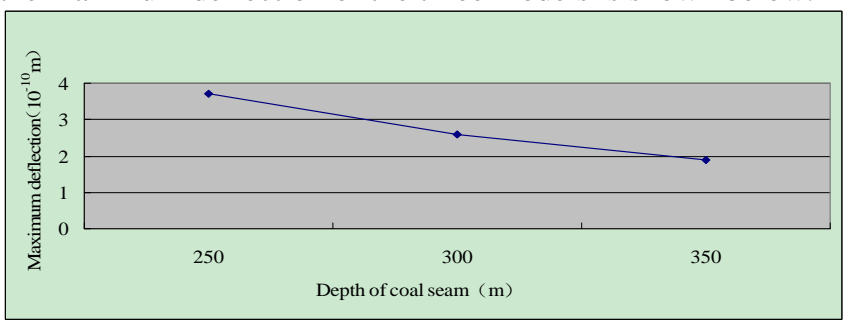

Figure 6. Thickness of the coal seam and the maximum deflection $\left(10^{-10} \mathrm{~m}\right)$ diagram

According to mechanical equation, it can be known that the greater the thickness of the rock layer, the smaller the deflection of the overburden rock is, because the rock stratum and the ratio of rock and soil are not changed, the thickness of the rock mass is constant, and the thickness of the rock is proportional to the thickness of the rock.

In general, the greater the pressure in the overlying strata is, the greater the maximum tensile stress and the maximum deflection of the coal-bearing strata will be, and the stability of the overlying strata will decrease as the buried depth increases, Which is due to the coal seam in the same depth conditions, the greater the thickness of the overlying bedrock thickness of the topsoil will be smaller. The reason is that the elastic modulus of the soil layer is smaller than the elastic modulus of the rock mass. Under the same external force, the soil will have a greater compression and extrusion, if the surface layer Increase, surface subsidence will become larger. This conclusion is consistent with the actual situation in the mining operations: other conditions remain unchanged, the deeper the mining depth, coal mining formed after the impact on the mined-out area on the ground the smaller.

\section{The Influence of Different Factors on the Maximum Tensile Stress and Deflection of Rock Mass}

According to the above conclusions, the maximum tensile stress and deflection of rock mass is different from different coal seam burial depth, rock-soil ratio and rock 
layer number. In order to further to understand the influence of various factors of the maximum pull-Stress and deflection of the impact of size, this paper uses EXCLE multiple regression analysis of the above factors. The number of strata is $x_{1}$, the depth of coal seam is set to $x_{2}$, and the ratio of rock and soil is $\mathrm{x}_{3}$, the calculation results are as follows.

TABLE X. THE INFLUENCE OF DIFFERENT FACTORS ON THE MAXIMUM TENSILE STRESS AND DEFLECTION OF ROCK MASS

\begin{tabular}{|c|c|c|c|c|}
\hline $\begin{array}{c}\text { Influencing } \\
\text { factors }\end{array}$ & P-value & $\begin{array}{l}\text { The fitted equation (with } \\
\text { maximum tensile stress) }\end{array}$ & $\begin{array}{c}\begin{array}{c}\text { Correlation } \\
\text { coefficient }\end{array} \\
\end{array}$ & Variance \\
\hline $\begin{array}{c}\text { Number of } \\
\text { strata }\end{array}$ & 4.08E-09 & \multirow{3}{*}{$\begin{array}{c}\mathrm{y}=0.367831+0.019656 \mathrm{x}_{1}- \\
0.00095 \mathrm{x}_{2}-0.03991 \mathrm{x}_{3}\end{array}$} & \multirow{3}{*}{$\mathrm{R}^{2}=0.9954$} & \multirow{3}{*}{$\begin{array}{l}\text { Significance } \\
\mathrm{F}=1.78 \mathrm{E}-08\end{array}$} \\
\hline Buried depth & 0.00455 & & & \\
\hline $\begin{array}{l}\text { Ratio of rock to } \\
\text { soil }\end{array}$ & 1.57E-05 & & & \\
\hline $\begin{array}{l}\text { Influencing } \\
\text { factors }\end{array}$ & P-value & $\begin{array}{l}\text { The fitted equation (with } \\
\text { maximum deflection) }\end{array}$ & $\begin{array}{c}\text { Correlation } \\
\text { coefficient }\end{array}$ & Variance \\
\hline $\begin{array}{c}\text { Number of } \\
\text { strata }\end{array}$ & 1.63E-07 & \multirow{3}{*}{$\begin{array}{c}\mathrm{y}=5.184336+0.469431 \mathrm{x}_{1}- \\
0.02912 \mathrm{x}_{2}-0.9129 \mathrm{x}_{3}\end{array}$} & \multirow{3}{*}{$\mathrm{R}^{2}=0.9887$} & \multirow{3}{*}{$\begin{array}{l}\text { Significance } \\
\mathrm{F}=6.13 \mathrm{E}-07\end{array}$} \\
\hline Buried depth & 0.014223 & & & \\
\hline $\begin{array}{c}\text { Ratio of rock to } \\
\text { soil }\end{array}$ & 0.000562 & & & \\
\hline
\end{tabular}

From the fitting of different influence factors and the maximum tensile stress of the rock mass, it can be found that the $P$ values of the three factors are less than 0.05 , indicating that the three independent variables are related to the maximum tensile stress; $\mathrm{R}^{2}=0.9954$, And the maximum tensile stress is highly positive correlation; variance $\mathrm{F}$ ( $\mathrm{F}$ statistically significant statistic)and $\mathrm{P}$ value is $1.78 \times 10^{-8}$, this value is less than the significant level of 0.05 , so that the regression equation regression effect is significant. According to the fitting equation of the maximum influencing factors and the maximum tensile stress of rock mass, the maximum influencing factor of rock stress is rock strata , and the minimum factor are the thickness of burial depth . In addition, it can be seen that with the increase in sand layers, the decrease of bedrock thickness and rock-soil ratio will cause the maximum tensile stress of rock mass to increase.

From the fitting of the different factors and the maximum deflection of the rock mass, it can be found that the $\mathrm{P}$ values of the rock stratum and the rock and soil ratio of the three factors are less than 0.05, Indicating that these two independent variables are related to the maximum deflection. In the table, $\mathrm{R}^{2}=0.9887$ is shown , showing that the three factors are highly positively correlated with the maximum tensile stress ; the $\mathrm{P}$ value of the variance $\mathrm{F}$ ( $\mathrm{F}$ statistically significant ) is $6.13 \times 10^{-7}$, which is less than the significance level of 0.05 , So that the regression equation regression effects is significant . According to the fitting equation of the different factors and the maximum tensile stress of the rock mass, the most influential factors affecting the rock mass deflection are the rock-soil ratio, the smallest factor is the sand layer number, and the depth and the thickness are not related to the maximum deflection. At the same time, it can be found that the maximum deflection of the rock mass increases in the increase in rock layer.

\section{CONCLUSION AND OUTLOOK}

- In the whole section of fine-grained interbedded structure, the thickness of overburden strata, the thickness of buried depth and the ratio of rock and soil will influence the stability of overburden rock, and have a great relation with the occurrence of mining subsidence.

- The maximum tensile stress of the overlying strata increases from the increase in the quantity of rock strata of the coal-bearing strata, but the increase in the rock-soil ratio and the depth of the buried strata causes the tensile stress becomes smaller. The maximum deflection of the overlying strata are increased by the increase in the quantity of rock strata of the coal-bearing strata in the inter-layer structure. However, the increase in the rock-soil ratio and the thickness of the buried strata causes the maximum deflection becomes small.

- In the whole section of fine-grained interbedded structure, the number of overburden rock layers has the greatest influence on the stability of overlying strata, and the effect of overburden rock-rock ratio on the stability of overburden rock is secondary, Of the thickness of the overlying strata is the least; the depth of the buried depth and the ratio of rock to soil are favorable for the stability of the overlying strata, but the increase of the strata of the overlying strata is disadvantageous to the stability of the overburden.

Mining subsidence factors also included: mining height, top control distance, mining intensity, inclination and coal pillar size . In order to more accurately to predict and control the geological and environmental hazards caused by mining subsidence, more factors must be combined with the future research.

\section{ACKNOWLEDGMENT}

Financial support for this work is provided by the National Science Foundation for Young Scientists of China (NO.41402308), Scientific Research Program Funded by Shaanxi Provincial Education Department (NO.14JK1466), Cultivation Foundation of Xi' an University of Science and Technology (NO.201308), Scientific Research Foundation for Doctor of $\mathrm{Xi}^{\prime}$ an University of Science and Technology (NO.2014QDJ006), all of which are gratefully acknowledged.

\section{REFERENCES}

[1] Ma Beibei, Lu Chunxia, Lei Zhang,"China's coal resources development potential evaluation and development strategy," Resources Science. J. China,vol.2 , pp.224-229,2009.

[2] Song Shijie, "Study on stratum transfer prediction method of mining subsidence based on key mineral factors," Xi'an University of Science and Technology.D. Xi'an , July 2013.

[3] Song Zhenqi, "Practical mine pressure control ,"China University of Mining and Technology Pres.M. Xuzhou , 1988.

[4] Deng kazhong "Effect of rock mass in mining subsidence," China University of Mining and Technology.D. Xuzhou, 1993.

[5] Qian Minggao, Shi Ping wu, Xu Jialin, "Mine pressure and rock formation control (second edition)," China University of Mining and Technology Press.M. Xuzhou, 2010.

[6] Song Shijie, Zhao Xiaoguang, Wang Shuangming, "Effects of Sandstone Strata on Mining Subsidence in Overlying Strata of Coal Measures,” Coal Mine Safety.J. Vol.11,pp.60-63,November 2014. 
[7] Hu Haifeng, " Study on surface subsidence law and prediction of composite media with different soil - rock ratio,” Taiyuan University of Technology.D. Taiyuan ,July 2012. 